\title{
Erratum to: Animal Models of Alzheimer's Disease: Utilization of Transgenic Alzheimer's Disease Models in Studies of Amyloid Beta Clearance
}

\author{
Tarja Malm • Johanna Magga $\cdot$ Jari Koistinaho
}

Published online: 18 April 2012

(C) Springer Science+Business Media, LLC 2012

Erratum to: Curr Tran Geriatr Gerontol Rep 2012

DOI 10.1007/s13670-011-0004-z

Malm T, Magga J, Koistinaho J: Animal Models of Alzheimer's Disease: Utilization of Transgenic Alzheimer's Disease Models in Studies of Amyloid Beta Clearance. Curr Tran Geriatr Gerontol Rep 2012, doi:10.1007/s13670-011-0004-z.

This article was published in the March 2012 issue of Current Translational Geriatrics and Experimental Gerontology Reports (volume 1, issue 1).

The reference list and tables were erroneously printed, and are provided thusly in remedy.

The online version of the original article can be found at http://dx.doi.org/ 10.1007/s13670-011-0004-z.

T. Malm $\cdot$ J. Magga $\cdot$ J. Koistinaho $(\varangle)$

A.I. Virtanen Institute for Molecular Sciences,

University of Eastern Finland,

P.O. Box 1627, 70211 Kuopio, Finland

e-mail: Jari.Koistinaho@uef.fi

J. Magga

Institute of Biomedicine, Department of Pharmacology

and Toxicology, University of Oulu,

Oulu, Finland

J. Koistinaho

Department of Oncology, Kuopio University Hospital,

Kuopio, Finland 
Table 1 Microglial cytokine expression profiles in some Alzheimer's disease mouse models

\begin{tabular}{|c|c|c|c|c|}
\hline Study & AD mouse model & $\begin{array}{l}\text { Development of } \\
A \beta \text { pathology }\end{array}$ & Detection method & Cytokine expression profile \\
\hline Ruan et al. [82] & APPswe/PS1dE9 & 4 months & $\mathrm{IHC}$ & $\begin{array}{l}\text { TNF- } \alpha \uparrow \text { starting at age } 8 \text { mo } \\
\text { and IL- } 1 \beta, \text { IL- } 6 \text {, and MCP- } 1 \uparrow \\
\text { starting at age } 10 \text { mo }\end{array}$ \\
\hline Hickman et al. [17] & APPswe/PS1dE9 & 4 months & Isolated microglia; qPCR & $\begin{array}{l}\text { SRA, CD36, RAGE, insulysin, } \\
\text { neprilysin, and MMP-9 } \downarrow \text {; } \\
\text { IL- } 1 \beta \text { and TNF- } \alpha \uparrow \text { starting } \\
\text { at age } 8 \text { mo }\end{array}$ \\
\hline Abbas et al. [83] & $\operatorname{Tg} 2576$ & 9-11 months & IHC; in situ hybridization & $\begin{array}{l}\text { IFN- } \gamma \text { and IL- } 12 \uparrow \text { and IL- } 4 \downarrow \\
\text { starting at age } 9 \text { mo }\end{array}$ \\
\hline Patel et al. [18] & APPswe; APP/PS1 & $\begin{array}{l}11 \text { months in APPswe; } \\
10 \text { weeks in APP/PS1 }\end{array}$ & $\begin{array}{l}\text { Organotypic slice cultures; } \\
\text { multiplex cytokine assay }\end{array}$ & $\begin{array}{l}\text { IL- } 1 \alpha \text {, TNF- } \alpha \text {, GM-CSF, and IL- } 6 \uparrow \\
\text { at age } 15 \text { mo in both models. APP/PS1 } \\
\text { brain slices produced significantly } \\
\text { more IL-12p40, IL- } 1 \beta \text {, IL- } 1 \alpha \text {, TNF- } \alpha \text {, } \\
\text { GM-CSF, and IL- } 6 \text { compared to } \\
\text { APPswe brain slices. Cytokine } \\
\text { levels correlated with brain } \\
\text { A } \beta \text { in both models }\end{array}$ \\
\hline Jimenez et al. [19] & $\begin{array}{l}\text { PS1(M146L) x } \\
\text { APP751sl }\end{array}$ & $3-4$ months & Brain homogenates; qPCR & $\begin{array}{l}\text { TNF } \alpha, \text { iNOS, IL- } 1 \beta, \text { FASL, TRAIL, } \\
\text { nox } 1 \text {, and Cox } 2 \uparrow \text { at age } 18 \text { mo. } \\
\text { IL- } 1 \beta \uparrow \text { at age } 12 \text { mo }\end{array}$ \\
\hline Jimenez et al. [19] & $\begin{array}{l}\text { PS1(M146L) x } \\
\text { APP751sl }\end{array}$ & $3-4$ months & IHC & $\begin{array}{l}\text { Microglia in the near vicinity of } \\
\text { A } \beta \text { plaques were shown to adopt } \\
\text { an incomplete alternative activation } \\
\text { state characterized by elevation } \\
\text { of YM- } 1 \text { and absence of TNF- } \alpha \\
\text { and iNOS at age } 18 \text { mo }\end{array}$ \\
\hline
\end{tabular}

$A \beta$ beta amyloid; $A D$ Alzheimer's disease; FASL Fas ligand; GM-CSF granulocyte-macrophage colony-stimulating factor; $I F N-\gamma$ interferongamma; IHC immunohistochemistry; IL interleukin; iNOS inducible nitric oxide synthase; $M C P$ monocyte chemotactic protein-1; $M M P-9$ matrix metalloproteinase 9; $q P C R$ quantitative polymerase chain reaction; $R A G E$ receptor for advanced glycation endproducts; $S R A$ scavenger receptor A; $T N F-\alpha$ tumor necrosis factor alpha; TRAIL TNF-related apoptosis-inducing ligand 
Table 2 Role of specific myeloid cells or factors regulating myeloid cell migration or activity affiliated to A $\beta$ clearance in the animal models of AD

\begin{tabular}{|c|c|c|c|}
\hline Study & Cells/Factors & Model & Effect on $\mathrm{A} \beta$ burden \\
\hline Mildner et al. $[2 \cdot \bullet]$ & $\mathrm{BM} \mathrm{CCR}^{+}$cells & $\begin{array}{l}\mathrm{CCR}^{-/-} \mathrm{BM} \text { cell chimera in } \\
\text { APPswe/PS1 and Tg2576 mice }\end{array}$ & $\begin{array}{l}\text { Irradiation preconditioning and CCR } 2 \text { expression } \\
\text { in } \mathrm{BM} \text { cells are required for their brain } \\
\text { engraftment. Peripheral macrophages rather } \\
\text { than parenchymal microglia modulate } \mathrm{A} \beta \\
\text { deposition in } \mathrm{AD} \text { mice }\end{array}$ \\
\hline El Khoury et al. [5] & CCR2 & $\begin{array}{l}\mathrm{CCR}^{-/-} \text {mice crossed } \\
\text { with } \operatorname{Tg} 2576 \text { mice }\end{array}$ & $\begin{array}{l}\text { Absence of CCR } 2 \text { impairs microglia accumulation } \\
\text { and increases } A \beta \text { levels and mortality in AD mice }\end{array}$ \\
\hline Lebson et al. [30•] & $\mathrm{BM} \mathrm{CD} 11 \mathrm{~b}^{+}$cells & $\begin{array}{l}\text { Adoptive transfer of neprilysin- } \\
\text { transfected BM CD11b } \\
\text { cells into APP/PS1mice }\end{array}$ & $\begin{array}{l}\mathrm{BM} \text { CD } 11 \mathrm{~b}^{+} \text {cells home to } \mathrm{AD} \text { mouse } \\
\text { brain after adoptive transfer. Injection of } \\
\mathrm{CD} 11 \mathrm{~b}^{+} \text {cells expressing secreted form of } \\
\text { neprilysin is associated with reduced } \mathrm{A} \beta \text { burden }\end{array}$ \\
\hline $\begin{array}{l}\text { Grathwohl } \\
\text { et al. [58] }\end{array}$ & Microglia/CD11 $\mathrm{b}^{+}$cells & $\begin{array}{l}\mathrm{CD} 11 \mathrm{~b}^{+} \text {cell ablation in } \\
\text { APPPS } 1 \text { and APP } 23 \text { mice }\end{array}$ & $\begin{array}{l}\text { Nearly complete ablation of } \mathrm{CD} 11 \mathrm{~b}^{+} \text {cells } \\
\text { did not alter } \mathrm{A} \beta \text { levels in } \mathrm{AD} \text { mice within } \\
\text { the observation period of } 4 \text { weeks }\end{array}$ \\
\hline Town et al. [84] & CD11 $\mathrm{c}^{+}$TGF- $\beta^{+}$cells & $\begin{array}{l}\text { Dominant negative TGF- } \beta \\
\text { in CD11 } \mathrm{c}^{+} \text {cells in Tg2576 } \\
\text { and APPswe/PS1dE9 mice }\end{array}$ & $\begin{array}{l}\text { TGF- } \beta \text { deficiency in } \mathrm{CD} 11 \mathrm{c}^{+} \text {reduced parenchymal } \\
\text { and vascular } \mathrm{A} \beta \text { burden involving infiltration } \\
\text { of peripheral macrophages }\end{array}$ \\
\hline Zhu et al. [85] & CD45 & $\begin{array}{l}\mathrm{CD} 45^{-/-} \text {crossed with } \\
\text { APPswe/PS1dE9 mice }\end{array}$ & $\begin{array}{l}\text { CD45 deficiency promotes proinflammatory } \\
\text { microglial activation, reduces their } \\
\text { phagocytic activity, and increases } \\
\text { soluble and insoluble } A \beta \text { levels }\end{array}$ \\
\hline Hao et al. [86] & $\begin{array}{l}\text { Myeloid differentiation } \\
\text { factor } 88\end{array}$ & $\begin{array}{l}\mathrm{MyD}^{-/-} \text {BM cell chimera } \\
\text { in TgCRND8 and } \\
\text { APPswe/PS1dE9 mice }\end{array}$ & $\begin{array}{l}\text { MyD88 deletion in } \mathrm{BM} \text { cells attenuates } \\
\text { neuroinflammation, enhances } \mathrm{A} \beta \text { phagocytosis, } \\
\text { and reduces } \mathrm{A} \beta \text { burden }\end{array}$ \\
\hline $\begin{array}{l}\text { Lee et al. [87] and } \\
\text { Liu et al. [88] }\end{array}$ & CX3CR1 & $\begin{array}{l}\text { CX } 3 C R 1^{-/} \text {crossed with } \\
\text { APPPS } 1 \text { mice }\end{array}$ & $\begin{array}{l}\text { Absence of CX3CR } 1 \text { leads to altered inflammation, } \\
\text { enhancement of microglia } A \beta \text { phagocytosis, } \\
\text { and reduction of } A \beta \text { burden }\end{array}$ \\
\hline $\begin{array}{l}\text { Reed-Geaghan } \\
\text { et al. [89] }\end{array}$ & CD14 & $\begin{array}{l}\mathrm{CD} 14^{-/-} \text {crossed with } \\
\text { APPswe/PS1dE9 mice }\end{array}$ & $\begin{array}{l}\text { TLR co-receptor CD14 deficiency alters microglia } \\
\text { activation and reduces microgliosis and } A \beta \text { burden }\end{array}$ \\
\hline Song et al. [90] & TLR4 & $\begin{array}{l}\text { TLR4 mutation mice crossed } \\
\text { with APPswe/PS1dE9 mice }\end{array}$ & $\begin{array}{l}\text { TLR mutation decreases microglia activation and } \\
\text { increases } A \beta \text { deposition in early AD possibly } \\
\text { involving reduced } A \beta \text { clearance }\end{array}$ \\
\hline Doi et al. [91] & TLR9 ligand & $\begin{array}{l}\text { TLR9 ligand CpG injection } \\
\text { (i.c.v) into Tg2576 mice }\end{array}$ & $\begin{array}{l}\text { TLR9 ligand } \mathrm{CpG} \text { reduces } A \beta \text { burden and } \\
\text { increases microglial production of degrading } \\
\text { enzymes and reduction of } A \beta\end{array}$ \\
\hline Keene et al. [92] & EP2 & $\begin{array}{l}\mathrm{EP} 2^{-/-} \text {BM cell chimera in } \\
\text { APPswe/PS1dE9 mice }\end{array}$ & EP2 deletion in $\mathrm{BM}$ cells reduces $\mathrm{A} \beta$ burden \\
\hline $\begin{array}{l}\text { Terwel et al. [93] and } \\
\text { Fitz et al. [94] }\end{array}$ & Liver $\mathrm{X}$ receptor & $\begin{array}{l}\text { LXR agonist p.o. into APP } 23 \\
\text { mice, } \text { LXR }^{-1-} \text { crossed with } \\
\text { APPswe/PS1dE9 mice }\end{array}$ & $\begin{array}{l}\text { LXR agonist reduces } A \beta \text { burden in } A D \text { mice } \\
\text { on high-fat diet. Astrocytic LXR activation } \\
\text { and the release of ApoE are involved in } \\
\text { microglial } A \beta \text { phagocytosis }\end{array}$ \\
\hline Maier et al. [95] & $\begin{array}{l}\text { Complement } \\
\text { factor } \mathrm{C} 3\end{array}$ & $\mathrm{C} 3^{-/-}$crossed with APP mice & $\begin{array}{l}\text { Absence of } \mathrm{C} 3 \text { drives microglia into } \mathrm{M} 2 \text { alternative } \\
\text { activation phenotype and increases } \mathrm{A} \beta \text { burden }\end{array}$ \\
\hline $\begin{array}{l}\text { Chakrabarty } \\
\text { et al. [96] }\end{array}$ & IL-6 & $\begin{array}{l}\text { AAV1-induced IL-6 } \\
\text { overexpression in brain } \\
\text { of TgCRND8 and } \\
\text { Tg2576 mice }\end{array}$ & $\begin{array}{l}\text { Overexpression of IL- } 6 \text { leads to massive } \\
\text { gliosis, and attenuates A } \beta \text { deposition by } \\
\text { enhanced microglia activation and possibly } \\
\text { by increased } A \beta \text { phagocytosis }\end{array}$ \\
\hline Shaftel et al. [97] & IL-1 $\beta$ & $\begin{array}{l}\text { Overexpression of IL-1 } \beta \text { in brain } \\
\text { of APPswe/PS1dE9 mice }\end{array}$ & $\begin{array}{l}\text { Sustained overexpression of IL- } 1 \beta \text { enhances } \\
\text { microglia activation and reduces } A \beta \text { burden }\end{array}$ \\
\hline $\begin{array}{l}\text { Boissonneault } \\
\text { et al. [98•] }\end{array}$ & MCSF & $\begin{array}{l}\text { Weekly i.p. injections } \\
\text { of MCSF into APPswe/PS1 }\end{array}$ & $\begin{array}{l}\text { MCSF increases microgliosis and BM cell } \\
\text { infiltration and reduces } A \beta \text { burden by phagocytosis }\end{array}$ \\
\hline
\end{tabular}

$A \beta$ beta amyloid; $A A V$ adeno-associated virus; $A D$ Alzheimer's disease; $a p o E$ apolipoprotein E; $B M$ bone marrow; $E P 2$ prostaglandin E2 receptor subtype 2; i.c.v. intracerebroventricular; IL interleukin; i.p. intraperitoneal; LXR liver x receptor; MCSF macrocyte colony-stimulating factor; p.o. per oral; $T G F-\beta^{+}$transforming growth factor beta; TLR 9 toll-like receptor 9 


\section{References}

Papers of particular interest, published recently, have been highlighted as:

- Of importance

•- Of major importance

1. Mildner A, Schmidt H, Nitsche M, et al. Microglia in the adult brain arise from Ly-6ChiCCR2+ monocytes only under defined host conditions. Nat Neurosci. 2007;10:1544-53.

2. . Mildner A, Schlevogt B, Kierdorf K, et al. Distinct and nonredundant roles of microglia and myeloid subsets in mouse models of Alzheimer's disease. J Neurosci. 2011;31:11159-71. This article describes important findings on myeloid subsets and CCR2 regulating their migration and functional properties in AD model in vivo.

3. Koistinaho M, Koistinaho J. Interactions between Alzheimer's disease and cerebral ischemia-focus on inflammation. Brain Res Brain Res Rev. 2005;48:240-50.

4. Simard AR, Soulet D, Gowing G, et al. Bone marrow-derived microglia play a critical role in restricting senile plaque formation in Alzheimer's disease. Neuron. 2006;49:489-502.

5. El Khoury J, Toft M, Hickman SE, et al. Ccr2 deficiency impairs microglial accumulation and accelerates progression of Alzheimerlike disease. Nat Med. 2007;13:432-8.

6. Majumdar A, Chung H, Dolios G, et al. Degradation of fibrillar forms of Alzheimer's amyloid beta-peptide by macrophages. Neurobiol Aging. 2008;29:707-15.

7. Fiala M, Cribbs DH, Rosenthal M, Bernard G. Phagocytosis of amyloid-beta and inflammation: two faces of innate immunity in Alzheimer's disease. J Alzheimers Dis. 2007;11:457-63.

8. Duyckaerts C, Potier MC, Delatour B. Alzheimer disease models and human neuropathology: similarities and differences. Acta Neuropathol. 2008;115:5-38.

9. Gotz J, Ittner LM. Animal models of Alzheimer's disease and frontotemporal dementia. Nat Rev Neurosci. 2008;9:532-44.

10. Ginhoux F, Greter M, Leboeuf M, et al. Fate mapping analysis reveals that adult microglia derive from primitive macrophages. Science. 2010;330(6005):841-5.

11. Mizutani M, Pino PA, Saederup N, et al. The fractalkine receptor but not CCR2 is present on microglia from embryonic development throughout adulthood. J Immunol. 2011, In press.

12. Mandrekar-Colucci S, Landreth GE. Microglia and inflammation in Alzheimer's disease. CNS Neurol Disord Drug Targets. 2010;9:15667.

13. Akiyama $\mathrm{H}$, Barger $\mathrm{S}$, Barnum $\mathrm{S}$, et al. Inflammation and Alzheimer's disease Neurobiol Aging. 2000;21:383-421.

14. Michelucci A, Heurtaux T, Grandbarbe L, et al. Characterization of the microglial phenotype under specific pro-inflammatory and anti-inflammatory conditions: Effects of oligomeric and fibrillar amyloid-beta. J Neuroimmunol. 2009;210:3-12.

15. Hoozemans JJ, Veerhuis R, Rozemuller JM, Eikelenboom P. Neuroinflammation and regeneration in the early stages of Alzheimer's disease pathology. Int J Dev Neurosci. 2006;24:157-65.

16. Jankowsky JL, Fadale DJ, Anderson J, et al. Mutant presenilins specifically elevate the levels of the 42 residue beta-amyloid peptide in vivo: evidence for augmentation of a 42-specific gamma secretase. Hum Mol Genet. 2004;13:159-70.

17. Hickman SE, Allison EK. El Khoury J: Microglial dysfunction and defective beta-amyloid clearance pathways in aging Alzheimer's disease mice. J Neurosci. 2008;28:8354-60.

18. Patel NS, Paris D, Mathura V, Quadros AN, et al. Inflammatory cytokine levels correlate with amyloid load in transgenic mouse models of Alzheimer's disease. J Neuroinflammation. 2005;2:9.
19. Jimenez S, Baglietto-Vargas D, Caballero C, et al. Inflammatory response in the hippocampus of PS1M146L/APP751SL mouse model of Alzheimer's disease: age-dependent switch in the microglial phenotype from alternative to classic. J Neurosci. 2008;28:11650-61.

20. Bolmont T, Haiss F, Eicke D, et al. Dynamics of the microglial/ amyloid interaction indicate a role in plaque maintenance. J Neurosci. 2008;28:4283-92.

21. Heneka MT, Nadrigny F, Regen T, et al. Locus ceruleus controls Alzheimer's disease pathology by modulating microglial functions through norepinephrine. Proc Natl Acad Sci U S A. 2010;107:6058-63.

22. Fleisher-Berkovich S, Filipovich-Rimon T. Ben Shmuel S, et al.: Distinct modulation of microglial amyloid beta phagocytosis and migration by neuropeptides. J Neuroinflammation. 2010;7:61.

23. Fiala M, Liu QN, Sayre J, et al. Cyclooxygenase-2-positive macrophages infiltrate the Alzheimer's disease brain and damage the blood-brain barrier. Eur J Clin Invest. 2002;32:360-71.

24. Auffray C, Sieweke MH, Geissmann F. Blood monocytes: development, heterogeneity, and relationship with dendritic cells. Annu Rev Immunol. 2009;27:669-92.

25. Malm T, Koistinaho M, Muona A, et al. The role and therapeutic potential of monocytic cells in Alzheimer's disease. Glia. 2010;58:889-900.

26. Malm TM, Koistinaho M, Parepalo M, et al. Bone-marrow-derived cells contribute to the recruitment of microglial cells in response to beta-amyloid deposition in APP/PS1 double transgenic Alzheimer mice. Neurobiol Dis. 2005;18:134-42.

27. Simard AR, Rivest S. Bone marrow stem cells have the ability to populate the entire central nervous system into fully differentiated parenchymal microglia. FASEB J. 2004;18:998-1000.

28. Magga J, Savchenko E, Malm T, et al. Production of monocytic cells from bone marrow stem cells: therapeutic usage in Alzheimer's disease. J Cell Mol Med. 2011, In press.

29. Fiala M, Liu PT, Espinosa-Jeffrey A, et al. Innate immunity and transcription of MGAT-III and Toll-like receptors in Alzheimer's disease patients are improved by bisdemethoxycurcumin. Proc Natl Acad Sci U S A. 2007;104:12849-54.

30. - Lebson L, Nash K, Kamath S, et al. Trafficking CD11b-positive blood cells deliver therapeutic genes to the brain of amyloiddepositing transgenic mice. J Neurosci. 2010;30:9651-8. This article describes an applicable method to modify monocytes to enhance their phagocytic capacity in cell-based therapy in AD models in vivo.

31. De Strooper B. Proteases and proteolysis in Alzheimer disease: a multifactorial view on the disease process. Physiol Rev. 2010;90:465-94.

32. Nagele RG, Wegiel J, Venkataraman V, et al. Contribution of glial cells to the development of amyloid plaques in Alzheimer's disease. Neurobiol Aging. 2004;25:663-74.

33. Mandrekar S, Jiang Q, Lee CY, et al. Microglia mediate the clearance of soluble Abeta through fluid phase macropinocytosis. J Neurosci. 2009;29:4252-62.

34. Yang CN, Shiao YJ, Shie FS, et al. Mechanism mediating oligomeric Abeta clearance by naive primary microglia. Neurobiol Dis. 2011;42:221-30.

35. Reed-Geaghan EG, Savage JC, Hise AG, Landreth GE. CD14 and toll-like receptors 2 and 4 are required for fibrillar A $\{$ beta $\}$-stimulated microglial activation. J Neurosci. 2009;29:11982-92.

36. Richard KL, Filali M, Prefontaine P, Rivest S. Toll-like receptor 2 acts as a natural innate immune receptor to clear amyloid beta 1-42 and delay the cognitive decline in a mouse model of Alzheimer's disease. J Neurosci. 2008;28:5784-93.

37. Koenigsknecht J, Landreth G. Microglial phagocytosis of fibrillar beta-amyloid through a betal integrin-dependent mechanism. J Neurosci. 2004;24:9838-46.

38. Gaikwad S, Larionov S, Wang Y, et al. Signal regulatory proteinbeta1: a microglial modulator of phagocytosis in Alzheimer's disease. Am J Pathol. 2009;175:2528-39. 
39. Frank S, Burbach GJ, Bonin M, et al. TREM2 is upregulated in amyloid plaque-associated microglia in aged APP23 transgenic mice. Glia. 2008;56:1438-47.

40. Bu G. Apolipoprotein E and its receptors in Alzheimer's disease: pathways, pathogenesis and therapy. Nat Rev Neurosci. 2009;10:333-44.

41. - Zhao L, Lin S, Bales KR, et al. Macrophage-mediated degradation of beta-amyloid via an apolipoprotein $\mathrm{E}$ isoform-dependent mechanism. J Neurosci. 2009;29:3603-12. This article describes important findings on ApoE isoform-dependent function of phagocytic cells in A $\beta$ clearance. Also, in vitro and ex vivo methods to study A $\beta$ phagocytosis are nicely covered.

42. Paresce DM, Chung H, Maxfield FR. Slow degradation of aggregates of the Alzheimer's disease amyloid beta-protein by microglial cells. J Biol Chem. 1997;272:29390-7.

43. Horvath RJ, Nutile-McMenemy N, Alkaitis MS, Deleo JA. Differential migration, LPS-induced cytokine, chemokine, and NO expression in immortalized BV-2 and HAPI cell lines and primary microglial cultures. J Neurochem. 2008;107:557-69.

44. Henn A, Lund S, Hedtjarn M, et al. The suitability of BV2 cells as alternative model system for primary microglia cultures or for animal experiments examining brain inflammation. ALTEX. 2009;26:83-94.

45. Nagai A, Nakagawa E, Hatori K, et al. Generation and characterization of immortalized human microglial cell lines: expression of cytokines and chemokines. Neurobiol Dis. 2001;8:1057-68.

46. Floden AM, Combs CK. Beta-amyloid stimulates murine postnatal and adult microglia cultures in a unique manner. $\mathrm{J}$ Neurosci. 2006;26:4644-8.

47. Moussaud S, Draheim HJ. A new method to isolate microglia from adult mice and culture them for an extended period of time. J Neurosci Methods. 2010;187:243-53.

48. Njie EG, Boelen E, Stassen FR, et al. Ex vivo cultures of microglia from young and aged rodent brain reveal age-related changes in microglial function. Neurobiol Aging. 2010.

49. Walker DG, Lue LF. Investigations with cultured human microglia on pathogenic mechanisms of Alzheimer's disease and other neurodegenerative diseases. J Neurosci Res. 2005;81:412-25.

50. Saura J, Tusell JM, Serratosa J. High-yield isolation of murine microglia by mild trypsinization. Glia. 2003;44:183-9.

51. Shimizu E, Kawahara K, Kajizono M, et al. IL-4-induced selective clearance of oligomeric beta-amyloid peptide $(1-42)$ by rat primary type 2 microglia. J Immunol. 2008;181:6503-13.

52. Stolzing A, Grune T. Impairment of protein homeostasis and decline of proteasome activity in microglial cells from adult Wistar rats. J Neurosci Res. 2003;71:264-71.

53. Zaghi J, Goldenson B, Inayathullah M, et al. Alzheimer disease macrophages shuttle amyloid-beta from neurons to vessels, contributing to amyloid angiopathy. Acta Neuropathol. 2009;117:11124

54. Yamamoto M, Kiyota T, Walsh SM, et al. Cytokine-mediated inhibition of fibrillar amyloid-beta peptide degradation by human mononuclear phagocytes. J Immunol. 2008;181:3877-86.

55. Wyss-Coray T, Loike JD, Brionne TC, et al. Adult mouse astrocytes degrade amyloid-beta in vitro and in situ. Nat Med. 2003;9:453-7.

56. Koistinaho $\mathrm{M}$, Lin $\mathrm{S}, \mathrm{Wu} \mathrm{X}$, et al. Apolipoprotein $\mathrm{E}$ promotes astrocyte colocalization and degradation of deposited amyloid-beta peptides. Nat Med. 2004;10:719-26.

57. Butovsky O, Kunis G, Koronyo-Hamaoui M, Schwartz M. Selective ablation of bone marrow-derived dendritic cells increases amyloid plaques in a mouse Alzheimer's disease model. Eur J Neurosci. 2007;26:413-6.

58. Grathwohl SA, Kalin RE, Bolmont T, et al. Formation and maintenance of Alzheimer's disease beta-amyloid plaques in the absence of microglia. Nat Neurosci. 2009;12:1361-3.
59. Stalder AK, Ermini F, Bondolfi L, et al. Invasion of hematopoietic cells into the brain of amyloid precursor protein transgenic mice. $\mathrm{J}$ Neurosci. 2005;25:11125-32.

60. Nikolic WV, Hou H, Town T, et al. Peripherally administered human umbilical cord blood cells reduce parenchymal and vascular betaamyloid deposits in Alzheimer mice. Stem Cells Dev. 2008;17:423-39.

61. Higuchi M, Maeda J, Ji B, et al. In-vivo visualization of key molecular processes involved in Alzheimer's disease pathogenesis: Insights from neuroimaging research in humans and rodent models. Biochim Biophys Acta. 2010;1802:373-88.

62. Teipel SJ, Kaza E, Hadlich S, et al. Automated detection of amyloid-beta-related cortical and subcortical signal changes in a transgenic model of Alzheimer's disease using high-field MRI. J Alzheimers Dis. 2011;23:221-37.

63. Meyer-Luehmann M, Spires-Jones TL, Prada C, et al. Rapid appearance and local toxicity of amyloid-beta plaques in a mouse model of Alzheimer's disease. Nature. 2008;451:720-4.

64. •• Hefendehl JK, Wegenast-Braun BM, et al. Long-term in vivo imaging of beta-amyloid plaque appearance and growth in a mouse model of cerebral beta-amyloidosis. J Neurosci. 2011;31:624-9. This article describes an in vivo method for long term tracking on single $A \beta$ deposits over time. Revealing the dynamics of $A \beta$ deposition is of high importance in understanding the disease mechanisms and for evaluation of $A D$ therapy.

65. Malm T, Ort M, Tahtivaara L, et al. beta-Amyloid infusion results in delayed and age-dependent learning deficits without role of inflammation or beta-amyloid deposits. Proc Natl Acad Sci U S A. 2006;103:8852-7.

66. Malm TM, Iivonen H, Goldsteins G, et al. Pyrrolidine dithiocarbamate activates Akt and improves spatial learning in APP/PS1 mice without affecting beta-amyloid burden. J Neurosci. 2007;27:3712-21.

67. Cheng IH, Scearce-Levie K, Legleiter J, et al. Accelerating amyloid-beta fibrillization reduces oligomer levels and functional deficits in Alzheimer disease mouse models. J Biol Chem. 2007;282:23818-28.

68. Lesne S, Kotilinek L, Ashe KH. Plaque-bearing mice with reduced levels of oligomeric amyloid-beta assemblies have intact memory function. Neuroscience. 2008;151:745-9.

69. Morgan D. Immunotherapy for Alzheimer's disease. J Intern Med. 2011;269:54-63.

70. Okun E, Mattson MP, Arumugam TV. Involvement of Fc receptors in disorders of the central nervous system. Neuromolecular Med. 2010;12:164-78.

71. Du Y, Dodel R, Hampel H, et al. Reduced levels of amyloid betapeptide antibody in Alzheimer disease. Neurology. 2001;57:801-5.

72. Britschgi M, Olin CE, Johns HT, et al. Neuroprotective natural antibodies to assemblies of amyloidogenic peptides decrease with normal aging and advancing Alzheimer's disease. Proc Natl Acad Sci U S A. 2009;106:12145-50.

73. Istrin G, Bosis E, Solomon B. Intravenous immunoglobulin enhances the clearance of fibrillar amyloid-beta peptide. J Neurosci Res. 2006;84:434-43.

74. Magga J, Puli L, Pihlaja R, et al. Human intravenous immunoglobulin provides protection against Abeta toxicity by multiple mechanisms in a mouse model of Alzheimer's disease. J Neuroinflammation. 2010;7:90.

75. Kellner A, Matschke J, Bernreuther C, et al. Autoantibodies against beta-amyloid are common in Alzheimer's disease and help control plaque burden. Ann Neurol. 2009;65:24-31.

76. Butovsky O, Koronyo-Hamaoui M, Kunis G, et al. Glatiramer acetate fights against Alzheimer's disease by inducing dendriticlike microglia expressing insulin-like growth factor 1 . Proc Natl Acad Sci U S A. 2006;103:11784-9.

77. Takata K, Kitamura Y, Saeki M, et al. Galantamine-induced amyloid\{beta\} clearance mediated via stimulation of microglial nicotinic acetylcholine receptors. J Biol Chem. 2010;285:40180-91. 
78. Smith AM, Gibbons HM, Dragunow M. Valproic acid enhances microglial phagocytosis of amyloid-beta(1-42). Neuroscience. 2010;169:505-15.

79. Tolon RM, Nunez E, Pazos MR, et al. The activation of cannabinoid CB2 receptors stimulates in situ and in vitro beta-amyloid removal by human macrophages. Brain Res. 2009;1283:148-54.

80. Masoumi A, Goldenson B, Ghirmai S, et al. 1alpha,25-dihydroxyvitamin D3 interacts with curcuminoids to stimulate amyloid-beta clearance by macrophages of Alzheimer's disease patients. J Alzheimers Dis. 2009; 17:703-17.

81. Farfara D, Trudler D, Segev-Amzaleg N, et al. gamma-Secretase component presenilin is important for microglia beta-amyloid clearance. Ann Neurol. 2011;69:170-80.

82. Ruan L, Kang Z, Pei G, Le Y. Amyloid deposition and inflammation in APPswe/PS1dE9 mouse model of Alzheimer's disease. Curr Alzheimer Res. 2009;6:531-40.

83. Abbas N, Bednar I, Mix E, et al. Up-regulation of the inflammatory cytokines IFN-gamma and IL-12 and down-regulation of IL-4 in cerebral cortex regions of APP(SWE) transgenic mice. J Neuroimmunol. 2002;126:50-7.

84. Town T, Laouar Y, Pittenger C, et al. Blocking TGF-beta-Smad2/3 innate immune signaling mitigates Alzheimer-like pathology. Nat Med. 2008;14:681-7.

85. Zhu Y, Hou H, Rezai-Zadeh K, et al. CD45 deficiency drives amyloid-beta peptide oligomers and neuronal loss in Alzheimer's disease mice. J Neurosci. 2011;31:1355-65.

86. Hao W, Liu Y, Liu S, et al. Myeloid differentiation factor 88deficient bone marrow cells improve Alzheimer's disease-related symptoms and pathology. Brain. 2011;134:278-92.

87. Lee S, Varvel NH, Konerth ME, et al. CX3CR1 deficiency alters microglial activation and reduces beta-amyloid deposition in two Alzheimer's disease mouse models. Am J Pathol. 2010;177:254962.

88. Liu Z, Condello C, Schain A, et al. CX3CR1 in microglia regulates brain amyloid deposition through selective protofibrillar amyloidbeta phagocytosis. J Neurosci. 2010;30:17091-101.

89. Reed-Geaghan EG, Reed QW, Cramer PE, Landreth GE. Deletion of CD14 attenuates Alzheimer's disease pathology by influencing the brain's inflammatory milieu. J Neurosci. 2010;30:15369-73.
90. Song M, Jin J, Lim JE, et al. TLR4 mutation reduces microglial activation, increases Abeta deposits and exacerbates cognitive deficits in a mouse model of Alzheimer's disease. J Neuroinflammation. 2011;8:92.

91. Doi Y, Mizuno T, Maki Y, et al. Microglia activated with the tolllike receptor 9 ligand $\mathrm{CpG}$ attenuate oligomeric amyloid beta neurotoxicity in in vitro and in vivo models of Alzheimer's disease. Am J Pathol. 2009;175:2121-32.

92. Keene CD, Chang RC, Lopez-Yglesias AH, et al. Suppressed accumulation of cerebral amyloid beta peptides in aged transgenic Alzheimer's disease mice by transplantation with wild-type or prostaglandin E2 receptor subtype 2-null bone marrow. Am J Pathol. 2010;177:346-54.

93. Terwel D, Steffensen KR, Verghese PB, et al. Critical role of astroglial apolipoprotein $\mathrm{E}$ and liver $\mathrm{X}$ receptor-alpha expression for microglial Abeta phagocytosis. J Neurosci. 2011;31:7049-59.

94. Fitz NF, Cronican A, Pham T, et al. Liver X receptor agonist treatment ameliorates amyloid pathology and memory deficits caused by high-fat diet in APP23 mice. J Neurosci. 2010;30:686272.

95. Maier M, Peng Y, Jiang L, et al. Complement C3 deficiency leads to accelerated amyloid beta plaque deposition and neurodegeneration and modulation of the microglia/macrophage phenotype in amyloid precursor protein transgenic mice. J Neurosci. 2008;28:6333-41.

96. Chakrabarty P, Jansen-West K, Beccard A, et al. Massive gliosis induced by interleukin- 6 suppresses Abeta deposition in vivo: evidence against inflammation as a driving force for amyloid deposition. FASEB J. 2010;24:548-59.

97. Shaftel SS, Kyrkanides S, Olschowka JA, et al. Sustained hippocampal IL-1 beta overexpression mediates chronic neuroinflammation and ameliorates Alzheimer plaque pathology. J Clin Invest. 2007; 117:1595-604.

98. • Boissonneault V, Filali M, Lessard M, et al. Powerful beneficial effects of macrophage colony-stimulating factor on beta-amyloid deposition and cognitive impairment in Alzheimer's disease. Brain. 2009;132:1078-92. This article describes a growth factor therapy toward myeloid cells that has high impact on microglia activation, reduction of $A \beta$ deposition, and improvement in cognitive function in $A D$ model in vivo. 